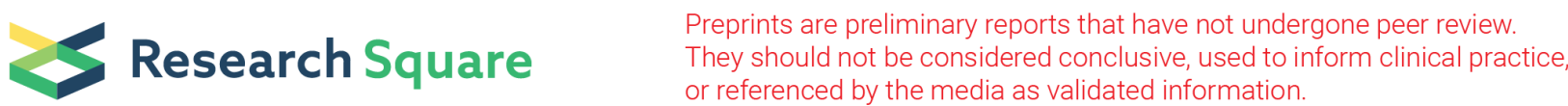

\section{Microbial quality of beef and hygiene practices in small and medium slaughterhouses and butcheries in Uganda}

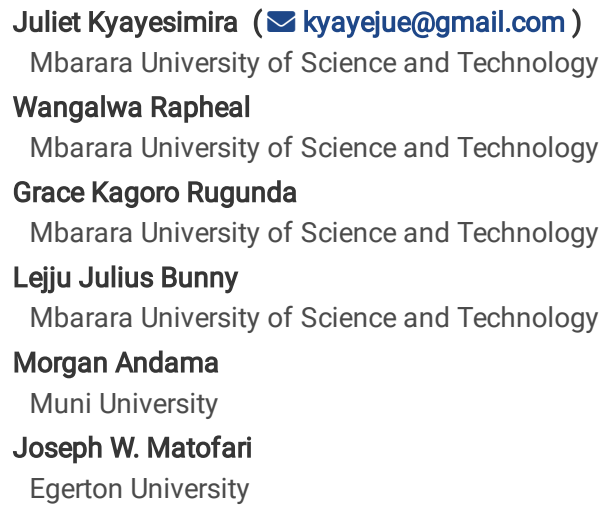

Data Article

Keywords: Beef, microbial quality, slaughter houses, butcheries, Uganda

Posted Date: July 29th, 2020

DOI: https://doi.org/10.21203/rs.3.rs-48693/v1

License: (c) (1) This work is licensed under a Creative Commons Attribution 4.0 International License. Read Full License 


\section{Abstract}

Background If hygiene practices along the beef processing nodes at small and medium enterprise (SME) slaughter houses and butcheries are not observed, they may pose a health risk due to microbial contamination. In SME slaughterhouses and butcheries, the risk may be higher due to transmission of foodborne pathogens. This study determined the hygienic practices and microbial quality risk among meat handlers (MH) in SME slaughterhouses and butcheries.

Methods Assessment of microbiological quality of beef was carried out at slaughter houses and butcher shops in the districts of Western, Central and Eastern regions of Uganda. A cross sectional study was conducted from June 2017 to January 2018 using observation checklists to record unhygienic practices among the various actors. Microbial load at slaughter and butchery was determined from a total of 317 swab samples collected from carcass, tools, protective clothing and hands of meat handlers. The microbiological quality of beef was evaluated using standard microbiological methods. The samples were inoculated into differential and selective media.

Results Butcheries had the highest microbial load on beef carcass ranging from $4.76 \log 10 \mathrm{cfu} / \mathrm{cm} 2$ to 7.90 log $10 \mathrm{cfu} / \mathrm{cm} 2$ Total Viable Counts (TVC) while Total Coliform Counts (TCC) ranged from $1.42 \log 10 \mathrm{cfu} / \mathrm{cm} 2$ to $3.05 \log 10 \mathrm{cfu} / \mathrm{cm} 2$, E. coli ranged from $0.68 \log 10 \mathrm{cfu} / \mathrm{cm} 2$ to $1.06 \log 10 \mathrm{cfu} / \mathrm{cm} 2 \mathrm{and}$ Staphylococcus aureus ranged from $3.25 \log 10 \mathrm{cfu} / \mathrm{cm} 2$ to $4.84 \log 10 \mathrm{cfu} / \mathrm{cm} 2$. Salmonella was absent in all the samples analysed. Results of overall microbial quality of beef in Uganda indicated that only TCC $(1.60 \pm 0.26 \log 10 \mathrm{cfu} / \mathrm{cm} 2)$ of the beef carcass samples at slaughter houses was not significantly above the safe level $(p=0.693)$. Overall microbial load $(T V C, T C C$, E. coli and $S$. aureus $)$ at butcheries were significantly $(p<0.05)$ above the safe level. Butcheries of Mbale district had the highest percentage (70\%) of beef carcass samples above the TCC safe levels whereas butcheries of Mbarara district had the highest percentage (40\%) of beef carcass samples above the E. coli safe levels. TVC from hands and clothes at butchery across the three study districts varied significantly $(\mathrm{p}=0.007)$ with the highest counts $(7.23 \log 10 \mathrm{cfu} / \mathrm{cm} 2)$ recorded from personnel clothes and lowest (5.46 log $10 \mathrm{cfu} / \mathrm{cm} 2)$ recorded from hands. On the other hand, swab samples picked from chopping board and working table at the butchery did not show significant variation in TVC, TCC, E. coli and S. aureus microbial loads across the three study districts.

Conclusion Hygienic handling of carcasses after slaughter is critical in preventing contamination and ensuring meat safety in informal meat trading sectors in Uganda. Handling practices of beef at Ugandan slaughterhouses and butcheries are not hygienic hence not up to standard and they contribute to microbial contamination of beef posing a risk to consumers. The distribution stage is the most critical period, during which the quality of meat can easily be compromised.

\section{Introduction}

In Uganda, beef sector has the highest per capita consumption of all meats and with the highest potential for local and regional growth in demand (Agriterra, 2012). However, handling of beef by actors in the chain from slaughter to butcheries is critical due to cross contamination by microorganisms. Unhygienic handling of beef by butchers and retailers during transportation, storage and improper sanitary conditions at the various retail outlets are leading sources of contamination (Obeng et al., 2013). In the absence of cold chain, the rate of microbial multiplication increases as well as carcass spoilage. Enteric and environmental pathogens that may contaminate the beef during handling along the chain become a risk for foodborne diseases (Assefa et al., 2015).

Hygienic handling of carcasses after slaughter is critical in preventing contamination and ensuring meat safety. The distribution stage (transportation) is the most critical period, especially if the beef is not stored or transported at the right temperature using the recommended containers. When meat is exposed to spoilage microorganisms from processing equipment like cutting knives, chopping tables, transportation containers and personnel, the microorganisms use the meat as a source of nutrients and energy for growth. This is because meat is highly perishable and contains nutrients required for microbial growth (Adams and Maurice, 2008). If hygienic measures are not adhered to in any food handling processes, spoilage and pathogenic microorganisms will come into contact with food and use the food as a source of nutrients to multiply and cause spoilage of the meat and illness to consumers (Assefa et al., 2015). Some of the pathogens associated with foodborne outbreaks include Staphylococcus aureus and gram-negative bacilli such as Salmonella spp., Shigella spp., Campylobacter jejuni; enterotoxigenic Escherichia coli as well as viral agents like hepatitis A and Norovirus. They have also been associated with food handlers and can survive on hands, skin, mouth, bruises, hair, sponges, clothes, and other surfaces for hours or days after the initial contact (Shojaei et al., 2006).

Beef handling in Uganda is underdeveloped with obsolete food laws and there is currently no institution or authority that is solely responsible for the Food safety in Uganda (Ejalu and Fortin, 2008). As a result, there is failure to develop trade partnerships with countries which have a developed food safety system. Unhygienic food handlers may transmit food borne diseases by cross contamination during storage under inappropriate conditions and also due to use of contaminated equipment (Al Suwaidi et al., 2015). Poor hygiene practices have been identified as contributing factors of food-borne outbreaks (PEH, 2008; Gilbert et al., 2007; Gorman et al., 2002).

The current practices in most of the animal slaughter houses and slaughter slabs in the urban and peri-urban areas in Uganda are non-standardized. For instance, facilities in abattoirs like bleeding rails, craddles, side stores for offal processing, blood pans and sanitary facilities for human use are mostly lacking and there is no separation of operational units. Humans without proper clothing are used to load and offload beef at slaughterhouses and butcheries. At the butchery, most premises are not made to specifications of selling meat products. There is no observation of hygiene in slaughterhouses due to lack of facilities like fly traps, water taps, water, sterile knives, washing basins and offal safes. At the butchery, equipment like chopping boards, tables and knives are never sanitized.

Practices of meat handling under conditions where such facilities are non-existent in a beef value chain poses a big challenge in meat safety and quality. Therefore, this study assessed the microbiological quality of beef at small and medium slaughter houses and butcheries in Uganda. 


\section{Materials And Methods \\ Study Area}

A cross sectional survey was carried out among SME slaughter houses and butcheries in major districts of Western, Central and Eastern regions of Uganda. These included districts of Mbarara (in Western region), Kampala (in Central region) and Mbale (in Eastern region) in Uganda (Fig. 1).

\section{Target actors and sampling technique}

A total of three hundred and seventeen (317) surface swab samples were collected from 42 facilities i.e. 4 slaughter houses and 10 retail meat outlets (butchery) from each of the three study districts of Mbarara, Kampala and Mbale as shown in Fig. 1. All the actively operating slaughter houses and butcheries (working daily) in Mbarara were purposively sampled. Similar number of facilities i.e. slaughter houses and butcheries were randomly sampled in Mbale and Mbarara using the same inclusion criteria. The swab samples were obtained from the hands and clothes of personnel, tools (Machete, Knives), surfaces (working tables, chopping board, floor) as shown in Table 1 and carcass (Table 2).

\section{Sample collection and preparation}

The surface swabs were aseptically collected from slaughter houses and butcheries. For surface swabbing, an area of approximately $10 \mathrm{~cm}^{2}$ was sampled by rolling and rubbing a sterile moist swab with the aid of a template (Microgen, 2016) from hands, surfaces of working benches, carcass, cutting tools or equipment and chopping boards. Swabs were collected from carcass, hands, clothes, working tables, cutting tools or equipment and chopping boards. The swabs were transferred into sterile transport medium (STUARTS), labelled and then placed in a cool box lined with ice packs awaiting transportation to the laboratory for examination (Da Silva et al., 2013). Observation check list was used to record unhygienic practices at slaughter houses and butchery.

\section{Determination of Microbial load}

Total Viable Counts: Microbiological analysis was carried out using standard methods (APHA, 2001; Adams and Maurice, 2008). The sample was inoculated by surface spreading onto standard Plate Count Agar (PCA). Serial 10-fold dilutions up to $10^{-8}$ were prepared. Dilutions of each sample were inoculated in duplicate in the standard plate count agar medium just before solidification of the agar. On solidification of agar, the plates were incubated at $37^{0} \mathrm{C}$ for 24 hours. After 24 hours of incubation, the colonies were counted using colony counter.

Total Coliforms Counts: The sample was inoculated by surface spreading onto Violet Red Bile Agar (VRBA) and incubation done at $37^{0} \mathrm{C}$ for $24-48$ hours. Pink colonies were observed, counted and expressed in colony forming units (CFU) per $\mathrm{cm}^{2}$.

Escherichia coli: The sample was inoculated by surface spreading onto Violet Red Bile Agar (VRBA) and incubated at $45^{\circ} \mathrm{C}$ for $24-48$ hours. Blue/violet colonies were observed and counted and expressed in colony forming units (CFU) per $\mathrm{cm}^{2}$.

Staphylococcus aureus. The sample was inoculated on Mannitol Salt Agar (Oxoid, UK) by surface spreading and the plates were incubated aerobically at $37^{0} \mathrm{C}$ for 24-48 hours.

Salmonella enterica: To the surface swabs aseptically collected, $90 \mathrm{ml}$ of $1 \%$ sterile peptone saline was added. The sample was incubated at $37^{0} \mathrm{C}$ for 24 hours (pre-enrichment phase). $1 \mathrm{ml}$ of the inoculum was placed in $10 \mathrm{ml}$ of Rappaport-Vassiliadis broth (selective enrichment phase) and incubated at $42^{0} \mathrm{C}$ for 24 hours. The resulting sample was inoculated on Xylose Lysine Dextrose (XLD) (Oxoid, UK) and incubated at $37^{\circ} \mathrm{C}$ for $24-48$ hours. Plates were read to look for brown, grey, green or black colonies with metallic sheen, colourless colonies with/without black centres. Selective plating was done on Tripple Sugar Iron (TSI) Agar (Oxoid, UK) slants and urea agar slant and incubated at $37^{\circ} \mathrm{C}$ for $24-48$ hours. Observation was done by looking for a red slant and yellow butt at times black spots on TSI slant. Then a pale-yellow slant on the urea agar slant was observed with the slide, and for agglutination test, suspect the salmonella colony with the poly 'o' salmonella antisera.

\section{Data Analysis}

Data was analyzed using descriptive statistics and presented as Mean \pm Standard Error of mean (SEM). Variations in the mean microbial counts among the three districts were also determined using one-way ANOVA and consequently least-significant difference (LSD) post hoc test for multiple comparison. One sample $t$ test was used to compare the overall microbial counts with microbial limit set by FAO/WHO. Independent samples t-test was used to test variations in microbial counts in slaughter houses and butcheries. Statistical analysis was run in SPSS ver. 20 (IBM Corp. Armonk, NY: Released 2011) at 5\% level of significance. Graphs were plotted using Microsoft excel ver. 2016. 


\section{Results}

\section{Mean microbial load $\left(\log _{10} \mathrm{cfu} / \mathrm{cm}^{2}\right)$ in Carcass at slaughter and butchery}

Fig 2 shows the mean microbial counts of carcass surface swabs collected from slaughter houses and butcheries (meat selling points). Mbarara district presented the highest TVC at both slaughter houses and butcheries with mean values of $6.17 \pm 0.58$ and $7.90 \pm 0.63$ log ${ }_{10} \mathrm{cfu} / \mathrm{cm}^{2}$ respectively. Statistical analysis indicated a significant difference in the TVC of meat samples across the three districts at both slaughter houses $(p=0.020)$ and butcheries $(p=$ 0.000). Mbale District had the highest TCC of $2.10 \pm 0.40$ and $3.05 \pm 0.22 \log _{10} \mathrm{cfu} / \mathrm{cm}^{2}$ at slaughter houses and butcheries respectively as compared to other districts. However, TCC did not vary significantly at both slaughter houses $(p=0.462)$ and butcheries $(p=0.108)$ across the three Districts. Samples from slaughter houses and butcheries of Mbarara district also had high $E$. coli counts of $0.71 \pm 0.32$ and $1.06 \pm 0.43 \log _{10} \mathrm{cfu} / \mathrm{cm}^{2}$ respectively compared to other Districts. Nonetheless, the variations were not statistically significant across the three Districts. Butcheries of Mbarara and slaughter houses of Mbale recorded the highest counts of $S$. aureus with mean values of $4.84 \pm 0.33$ and $3.72 \pm 0.57 \log _{10} \mathrm{cfu} / \mathrm{cm}^{2}$ respectively. However statistical analysis indicated significant variation at only butcheries across the three districts $(p=0.000)$.

Fig 3 shows the overall mean microbial load of surface swabs collected from hands, tools and personnel clothing at slaughter houses and butcheries (meat selling points) in Uganda based on overall samples collected from the three Districts. Personnel clothing from butcheries presented the highest TVC and $S$. aureus microbial load of $7.23 \pm 0.55$ and $4.56 \pm 0.54 \log _{10} \mathrm{cfu} / \mathrm{cm}^{2}$ respectively. On the other hand, machete at slaughter houses had the highest TCC and $E$ coli loads of $2.43 \pm 0.28$ and $0.73 \pm 0.25 \log _{10} \mathrm{cfu} / \mathrm{cm}^{2}$ respectively. However statistical analysis indicated significant variation in TVC $(p=0.003)$ and $S$. aureus $(p=$ $0.009)$ loads from machete, TVC $(p=0.007)$ and TCC $(p=0.016)$ loads from personnel clothing across the two nodes of the beef value chain. Samples from hands and knives did not vary significantly in microbial load across the two nodes of the beef value chain. Salmonella enterica was absent in all the samples analysed.

\section{Microbial counts $\left(\log _{10} \mathrm{cfu} / \mathrm{cm}^{2}\right)$ from tools, surfaces, personnel hands and clothes at slaughter and butchery}

Comparison of the microbial load from tools, surfaces, personnel hands and protective clothing in the three districts (Table 1) was as follows: Generally, swab samples from butchery operators had higher microbial load than slaughter house operators across the three districts.

On overall (all districts), personnel clothes of butchery operators had a significantly higher microbial load of TVC and $S$. aureus than hands, machete, knives, chopping board and working table $(p=0.000$ and $p=0.001$ respectively).

Personnel clothes of butchery operators from Mbarara district presented the highest TVC and $S$. aureus loads of $8.38 \pm 0.28$ and $5.05 \pm 0.71$ log $10 \mathrm{cfu} / \mathrm{cm}^{2}$ respectively compared to Mbale and Kampala districts.

Furthermore, butchery operators indicated high TCC microbial load $\left(3.82 \pm 0.60 \log _{10} \mathrm{cfu} / \mathrm{cm}^{2}\right)$ from machete in Mbale district whereas clothes had high $E$. coli microbial load $\left(1.91 \pm 0.65 \log _{10} \mathrm{cfu} / \mathrm{cm}^{2}\right)$ in Kampala. On overall, all swab samples indicated that Mbarara district had the highest TVC and $S$. aureus microbial load than Kampala and Mbale $(\mathrm{p}=0.000)$ at the butchery.

At slaughter houses, the highest microbial load was recorded for TVC $\left(8.32 \pm 0.27 \log _{10} \mathrm{cfu} / \mathrm{cm}^{2}\right)$ and $S$. aureus $\left(4.96 \pm 0.73\right.$ log $\left.10 \mathrm{cfu} / \mathrm{cm}^{2}\right)$ from personnel protective clothing in Mbarara district where as Mbale district had the highest TCC loads of $2.97 \pm 0.18 \log _{10} \mathrm{cfu} / \mathrm{cm}^{2}$ and Kampala District presented the highest $E$. coli loads of $1.79 \pm 0.62 \log _{10} \mathrm{cfu} / \mathrm{cm}^{2}$.

On overall (all districts), floors of slaughter houses had a higher microbial load of TVC whereas $S$. aureus microbial load was high in machete but did not vary significantly $(\mathrm{p}<0.05)$. Generally, all swab samples indicated that Mbarara district had the highest TVC and $S$. aureus microbial load than Kampala and Mbale $(p=0.000)$ at the slaughter houses but $E$. coli was highest in Kampala $(p=0.001)$. Pairwise comparisons of the microbial loads between districts and swab samples are shown in table 1 .

\section{Comparison of overall microbial quality of beef in Uganda with quality standards}

Table 2 summarizes the microbiological limits based on standards provided by (FAO/WHO, 2003; Codex, 2011; EC, 2018). Results indicated that at slaughter houses in Uganda only TCC $\left(1.60 \pm 0.26 \log _{10} \mathrm{cfu} / \mathrm{cm}^{2}\right)$ of the beef samples was not significantly different from the safe level $(p=0.693)$. Beef samples at butcheries were all significantly above the satisfactory (safe) level. Results in Fig. 4 further indicate that butcheries generally had a higher proportion of samples that did not conform to safe microbial levels than slaughter houses across the three districts. All carcass samples at butcheries from the three districts did not conform to the S. aureus safe levels. Butcheries in Mbale district had the highest percentage (70\%) of beef samples above the TCC safe levels whereas butcheries of Mbarara district had the highest percentage (40\%) of beef samples above the E. coli safe levels. However, Mbarara and Kampala recorded the highest percentage (80\%) of beef samples above the TVC safe levels. 


\section{Compliance of slaughter houses and butchery based on good practices}

Slaughter house and butchery establishments were assessed for compliance to standard operating practices through non participatory observations and the results are recorded in table 3 . The results indicate that the butcheries were less compliant (14-33\%) to the good operating practices as compared to slaughter houses (40-80\%) in the study area. Observation results revealed that floors were dirty, knives and other cutting tools were handled carelessly, weighing scales were unclean and all the butchery establishments lacked hand washing facilities. Observations made on handling of tools by slaughter operators showed that knives were kept in gum boots during the slaughter process. In all the study areas, the slaughter houses were found to carry out meat inspection by visual assessment. When these results from observation survey were compared with the microbial data results, it was established that butcheries had the highest microbial load compared to slaughter houses.

\section{Discussion}

\section{Mean microbial load $\left(\log _{10} \mathrm{cfu} / \mathrm{cm}^{2}\right)$ in Carcass at slaughter and butchery}

The higher microbial counts for TVC, TCC, E. coli and S. aureus in the carcass swabs obtained from the butcher shops (meat retail shops) than at slaughter houses showed that level of contamination in the meat shops was higher compared to the abattoir and these results relate to Bhandare et al. (2007). In another study in Kampala Uganda by Bogere \& Baluka (2014) contamination of meat with Coliforms and $E$. coli was higher at the butchery level than at the abattoir level. The higher microbial load at the butcheries is attributed to beef that is displayed mixed with offals openly on tables, structures with no screens hence attracted flies into the butcheries. Furthermore, the higher microbial load at the butchery relates to the results from observation where floors were found dirty, knives and other cutting tools were handled carelessly, weighing scales were unclean and all the butchery establishments lacked hand washing facilities Related studies indicate that the beef can be subjected to contamination from a variety of sources from within and outside the animal both at slaughter, transport and sale (Kumar et al., 2014; Adams \& Maurice, 2008). At slaughter, meat inspection covers only visual assessment, without considering microbiological tests (Rani et al., 2017) and this was similar to all the slaughter houses in all the study districts and microbial contaminated meat can end up being sold and hence made available to the consumers. Additionally, when meat is exposed to microorganisms which may be present on cutting knives, chopping tables and other equipment, it leads to spoilage thereby reducing the shelf life and quality of meat (Adzitey and Huda, 2012).

\section{Microbial counts $\left(\log _{10} \mathrm{cfu} / \mathrm{cm}^{2}\right.$ ) from tools, surfaces, personnel hands and clothes at slaughter and butchery}

The high microbial load in tools could be attributed to unhygienic handling at slaughter and this favours cross contamination. For example, from observations of the handling of tools by slaughter operators (butcher men), the knives were kept in gum boots during the slaughter process. In a study in Algeria, it was noted that during evisceration, unhygienic workers' behaviours make use of tools that have been in direct contact with skin and feaces of the animals at the slaughtering halls (Nouichi and Mossadak, 2009). Studies have reported that at the abattoir, the potential health risk to consumers is brought about by the presence of pathogens in meat and contaminated equipment (Birhanu et al., 2017). Microorganisms like Escherichia coli, Staphylococcus aureus and Salmonella spp are known to survive on surfaces for hours or days (Pérez-rodríguez et al., 2013) and so prevention of formation of biofilms on meat cutting equipment will prevent them from becoming media of cross-contamination among carcasses (Wambui et al., 2017).

At the butchery, besides using knives to cut meat, they are also used to scrap off chipped meat on tables (Chepkemoi et al., 2015) and other surfaces for example chopping stump or board. The high microbial loads on knives and machete recorded at the butchery in this study may be attributed to unsterilized knives and the unhygienic usage. A study by Chepkemoi (2016) found out that majority of butchery operators could be wiping the knives with a piece of cloth instead of washing according to Sanitation Standard Operating Procedures (SSOPs). During observations, different butcheries which operate close to each other were sharing cutting tools (knives and machete) among themselves and this could be a possible source of contamination. The carcass can get exposed to spoilage microorganisms during cutting and they may be present on cutting knives and other equipment. These microorganisms cause spoilage thereby reducing meat shelf life and its quality (Adzitey and Huda, 2012). Higher mean log values in the abattoir and butcher shops was also reported in a study (Birhanu et al, 2017), but was highest in butchery tools. The high microbial load on the knife is an indication of an inadequate cleaning and continuous use of a single knife despite contact with dirty or contaminated material surfaces (Birhanu et al., 2017). Research has shown that when contaminated equipment is used continuously for a long period of time, microorganisms initially present can multiply and act as a continuous source of contamination in the food produced subsequently (Ray, 2005).

The highest microbial load in personnel hands and clothes was found in butcher shops and this is similar to a study by Kebede et al. (2014). The higher TVC count in personnel hands and clothes can be attributed to lack of awareness by the butchery operators on good hygiene practices (Kebede et al., 2014) and hence unhygienic handling (Obeng et al., 2013). For example, handling money while serving food increased microbial contamination (Muinde and Kuria, 2005). In a study by Birhanu et al. (2017) the high microbial load in workers hands in the butcher was due to the fact that they handled money at the same time meat. The same hands were used to contact their hair, shake hands with friends or customers and absence of hand washing before and after serving meat to customers. 
The mean TVC and TCC from personnel hands and clothes were highest at the butchery than at slaughter. A similar study found out that the mean bacterial load was higher at the butchery level than at the abattoir (Bogere and Baluka, 2014). Observations indicated low adherence of butcher men in wearing protective clothing and the same people who handled meat received money and these could be the reasons of high microbial load contamination at butcheries (Chepkemoi et al., 2015). In a related study, hands were found to be a major source of infection from microorganisms in food stuffs (Kahraman et al., 2010). The butcheries were located along the road side and this exposed the meat to dust raised by automobiles (Bogere and Baluka, 2014). In the study, several butcheries were located next to each other and the butcher men shared weighing scales, stones and cutting tools and besides the microbial load increased with longer stay of meat at the butchery (Obeng et al., 2013). Some butcheries share refrigerators with retail shops hence meat is kept with other commodities such as beverages, water and other ready-to-eat foods (Mirembe et al., 2015) and this can be a source of contamination.

Slaughtering was done on the floor in all the slaughter houses in the study area and this way of handling animals on the slaughter floor can affect the quality of meat (RMAA, 2011). The animals were dragged into the slaughter house and slaughtered from the floor. They are even made to see carcasses of previously slaughtered animals which are a violation to animal rights and welfare (Fasae and Bakare, 2016). The floor was often dirty and with spills of blood from previous slaughter activity and this could be the reason why the slaughter floors were highly contaminated. Slaughtering and processing of carcass in the study areas was done on the floor of the slaughter house and this was usually contaminated from previous activities and hence potential source of microbial contamination. In another study, it was reported that flaying, evisceration and splitting of carcass were carried out on unhygienic floors and such practices increase chances of carcass contamination and leading to unsafe meat (Lawan et al., 2013).

Surfaces at the butchery include chopping board and working table where meat and offals are displayed. The high microbial loads on working tables and chopping boards at butchery were similar to the findings of (Chepkemoi, 2016) who observed that contamination of meat can occur during selling where surfaces like tables and chopping boards are contaminated.

Cleaning slaughter floor with cold water is unsatisfactory and if there was a supply of hot portable water in abattoirs, it would remove fatty nature of wastes at the abattoir. Additionally, washing with hot water and detergent facilitates easy and quality washing of abattoir floor (Lawan et al., 2013) and surfaces at the butchery. In Kenya, meat was found to be contaminated with microbial pathogen like E.coli and $S$. aurues due to poor handling practices post-slaughter and poor personnel hygiene (Chanzu et al., 2018) and the same applies to the current study.

From observations of slaughter operators, the protective clothing worn are very dirty and yet during meat carriage, the carcass comes into contact with them. This could be due to the fact that protective clothing wom at the slaughter houses are rarely cleaned and so harbour a lot of microorganisms. Additionally, the microbial load in clothes and hands could result from carcass contamination at the slaughter houses that comes from a variety of sources within and outside animal during the slaughter process. The contaminating organisms come mainly from the hide of the animal and the faeces (Kumar et al., 2014). For example in a study in Juba town-South Sudan, it was found out that slaughter operators do not wear protective clothing and sometimes, the men remove their shirts during the process (Andrea and Aburi, 2012). Generally, the high mean values of microbial load is as a result of poor handling of meat at the slaughtering places (Kebede et al., 2014). Moreover, poor hygienic practices expose food products to microbial contamination which reduce the shelf life and affect public health (Mwangi et al., 2016).

\section{Microbiological Contamination Of Carcass Samples Limits}

Carcass samples that fall in unsatisfactory levels are above expected microbiological levels and indicate poor food handling practices (Food standards Australia Newzeland, 2018). The presence of $E$. coli (faecal indicator organism) in the beef indicates direct or indirect faecal contamination and this suggests a general lack of cleanliness in handling and improper storage (Centre for Food safety, 2014). Research indicates that microbial contamination occurs at every phase of processing but can be reduced through use of proper sanitation equipment and personal hygiene (Maharjan et al., 2019). Results indicated high prevalence of $\mathrm{S}$. aureus in the carcass and relates to several studies that documented prevalence of $S$. aureus in many raw retail meats; an indication that consumers are at potential risk of $S$. aureus colonization and subsequent infection. Staphylococcal food-borne disease (SFD) is one of the most common food-borne diseases worldwide resulting from the contamination of food by preformed S. aureus enterotoxins (Kadariya et al., 2014; Das and Mazumder, 2016). Eventually, the microbial contaminated meat will lead to morbidity and mortality (Abdullahi et al., 2016) among the consumers if there is continuous non-compliance to Standard Operating Practices.

\section{Conclusion}

Observations indicated that the protective clothing worn by different actors were dirty and yet during meat carriage, the carcass comes into contact with them. Dirty protective clothing wom harbour a lot of microorganisms and this is a source of microbial contamination. For the surface swabs, the floor had the highest microbial counts compared to working table and chopping board/stamp. The fact that surfaces at the butchery like chopping board are never cleaned apart from scrapping off dirt using a knife, they act as micro-habitats for the microorganism. The carcass can get exposed to spoilage microorganisms during cutting which may be present on cutting knives and other equipment. Hygienic handling of carcasses after slaughter is critical in preventing contamination and ensuring meat safety in informal meat trading sectors in Uganda. Handling practices of beef at Ugandan slaughterhouses and butcheries are not hygienic hence not up to standard and they contribute to microbial contamination of beef posing a risk to consumers. The distribution stage is the most critical period, during which the quality of meat can easily be compromised. Generally, the butcher shops showed highest microbial contamination than slaughter houses. Therefore, actions are required to re-establish effective beef handling controls right from slaughter.

\section{Declarations}

\section{Ethical approval}


The research was approved by National ethics committee (Uganda National Council of Science and Technology (RELOAD/A401 UNCST 2012) and the University Research Ethics Committee (04/09-17).

\section{Availability of data and materials}

The datasets during and/or analysed during the current study available from the corresponding author on reasonable request.

\section{Conflict of interests}

The authors declare that there is no conflict of interests regarding the publication of this paper.

\section{Acknowledgement}

Authors thank the different actors in the beef value chain in the districts of Kampala, Mbarara and Mbale who gave us permission to collect samples and the meat inspectors at different slaughter houses for their cooperation. Special acknowledgement to Dr. Morgan Andama for the mentorship and support during this research. Special thanks to the field Assistants Twijukye Nicholas, Kintu Davis and Mugumya Morris for the assistance during sample collection and transportation. Finally, credit goes to the laboratory team at College of Veterinary Medicine, Animal Resources and Biosecurity (CoVAB) led by Mr. Musisi Nathan Lubowa for the support.

\section{Funding}

Special thanks for the financial support from the German Federal Ministry of Education and Research and the German Federal Ministry for Economic Cooperation and Development under the Reduction of Postharvest Losses and Value Addition in East African Food Value Chains Project (RELOAD/A401UNCST2012). The RELOAD Project is coordinated by Prof. Oliver Hensel and Michael Hesse at the University of Kassel in Witzenhausen, Germany.

\section{Authors' contribution}

This research work was part of Juliet Kyayesimira thesis research for the award of PhD in Biological Sciences of Mbarara University of Science and Technology. The research work was supervised by Grace Kagoro Rugunda, Lejju Julius Bunny \& Joseph W. Matofari. Juliet Kyayesimira was in-charge of administering observation checklists, sample collection and laboratory analysis while Dr. Morgan Andama and Wangalwa Rapheal were in charge of technical guidance during data analysis and manuscript review. All authors have been involved in the research design, data analysis, interpretation of results and manuscript writing. The authors have read and approved the final manuscript.

\section{Author's information}

Dr. Juliet Kyayesimira was a graduate student in the Department of Biology at Mbarara University of Science and Technology, Uganda where she completed her doctoral studies. She holds a Msc in Biology and Bsc Education from the same University. She has several years of working experience and lecturing in the field of Biological Sciences at Kyambogo University, Uganda.

Dr. Morgan Andama is a Dean and senior lecturer in the Department of Biology at Muni University, Uganda.

Wangalwa Rapheal is an Assistant Lecturer in the Department of Biology at Mbarara University of Science and Technology and a PhD student in the same University. Dr. Grace Kagoro Rugunda and Dr. Lejju Julius Bunny are associate professors in the Department of Biology at Mbarara University of Science and Technology while Dr. Joseph W. Matofari is a professor in the department of Dairy and Food Science and Technology, Egerton University, Kenya.

\section{References}

Abdullahi A, Hassan A, Kadarman N, Junaidu MY, Adeyemo OK. Occupational hazards among the abattoir workers associated with noncompliance to the meat processing and waste disposal laws in Malaysia. Risk Manag. Healthc. Policy. 2016;9(1):157-63.

Aburi SAP. Assessment of Hygiene practices used by Small Butchers and Slaughter Slabs in beef value chain in Juba town-South Sudan. Appl. Sci. J. 2012. Adams RM, Maurice OM. Food microbiology. 3rd Ed. Guildford, UK: RSC Publishing; 2008.

Adzitey F, Huda N. Effects of post-slaughter carcass handling on meat quality. Pak. Vet. J. 2012;32(2):161-4.

Agriterra. Identification of livestock investment opportunities in Uganda [Internet]. Arnhem, Netherlands; 2012. Available from: www.agriterra.org APHA. PDF Download Compendium of Compendium of methods for the Microbiological Examination of Foods , 4th Edition. 4th Editio. Downes FP, Ito K, editors. American Public Health Association (APHA) 2001-04-15; 2001. 
Assefa T, Tasew H, Wondafrash B, Beker J. Contamination of Bacteria and Associated Factors among Food Handlers Working in the Student Cafeterias of Jimma University Main Campus, Jimma, South West Ethiopia. Altern. Integr. Med. 2015;04(01).

Bhandare et al. A comparison of microbial contamination on sheep / goat carcasses in a modern Indian abattoir and traditional meat shops. Food Control. 2007;18:854-8.

Bogere P, Baluka AS. Microbiological Quality of Meat at the Abattoir and Butchery Levels in Kampala City , Uganda. Internet J. Food Saf. [Internet]. 2014;16:29-35. Available from:

https://www.researchgate.net/profile/Sylvia_Baluka/publication/281451512_Microbiological_Quality_of_Meat_at_the_Abattoir_and_Butchery_Levels_in_Kamp Accessed 15 March 2019

Centre for Food safety. Microbiological Guidelines for Food. 43/F, Queensway Government Offices, 66 Queensway, Hong Kong. 2014.

Chanzu O, Kunyanga CN, Imungi JK. Effects of Poor Post-slaughter Handling Practices on Microbiological Quality of Fresh Beef from Slaughterhouses in Kenya. Food Sci. Qual. Manag. 2018;78:17-22.

Chepkemoi S. Handling Practices, Microbial Quality and Weight Loss of Beef in Small and Medium Enterprise Butcheries in Nairobi and [Internet]. University of Nairobi; 2016. Available from: http://erepository.uonbi.ac.ke/bitstream/handle/11295/97748/Chepkemoi_Handling Practices, Microbial Quality And Weight Loss Of Beef In Small And Medium Enterprise Butcheries In Nairobi And Isiolo Counties, Kenya.pdf?sequence=1\&isAllowed=y. Accessed 10 March 2019

Chepkemoi S, Lamuka PO, Abong GO, Matofari J. Sanitation and Hygiene Meat Handling Practices in Small and Medium Enterprise butcheries in Kenya -Case Study of Nairobi and Isiolo Counties. Internet J. Food Saf. 2015;17(Irungu 2008):64-74.

Codex. Regulation on Turkish food codex microbiological criteria. 2011. Report No.: 5996.

Das P, Mazumder PB. Prevalence of Staphylococcus in raw meat samples in Southern Assam, India. J. Agric. Vet. Sci. [Internet]. 2016;9(1):23-9. Available from: http://www.iosrjournals.org/iosr-javs/papers/vol9-issue1/Version-2/D09122329.pdf

J18. B COMMISSION REGULATION (EC) No 2073/2005 of 15 November 2005 on microbiological criteria for foodstuffs. 2018. Report No.: $2073 / 2005$.

Ejalu BP, Fortin N. U.S. and Ugandan Food Safety Systems: A Challenge To Create Development Partners [Internet]. 2008. Available from:

https://www.canr.msu.edu/iflr/uploads/files/StudentPapers/US_Ugandan_Food_Safety_Systems.pdf. Accessed 18 Feb 2019

FAO/WHO. Codex alimentarius Commission: Working paper on elaboration of a regional Standard for microbiological levels in foods (prepared by Egypt). Cairo, Egypt; 2003. Report No.: CX/NEA 03/16.

Fasae OA, Bakare MO. Cattle handling, hygiene and slaughtering techniques in selected cattle markets in Abeokuta and environs , Ogun state , Nigeria. J. Agric. Sci. Environ. 2016;16(2):50-60.

Food standards Australia Newzeland. Compendium of Microbiological Criteria for Food [Internet]. Food Stand. Aust. New Zeal. 2016. Food Standards Australia New Zealand. This; 2018. Available from: http://www.foodstandards.gov.au/publications/Pages/Compendium-of-Microbiological-Criteria-forFood.aspx. Accessed 21 Feb 2019

Gilbert SE, Whyte R, Bayne G, Paulin SM, LAke RJ, Van der logt P. Survey of domestic food handling practices in New Zealand. Int. J. Food Microbiol. 2007;117(3):306-11.

Gorman R, Bloomfield S, Adley CC. A study of cross-contamination of food-borne pathogens in the domestic kitchen in the Republic of Ireland. Int. J. Food Microbiol. 2002;76(1-2):143-50.

Kadariya J, Smith C, Thapaliya D. Staphylococcus aureus and Staphylococcal Food-Borne Disease: An Ongoing Challenge in Public Health. Biomed Res. Int. 2014;2014.

Kebede et al. Assessment of Bacteriological Quality of Sold Meat in the Butcher Shops of Adigrat, Tigray, Ethiopia Bureau of Agriculture and Rural Development. Appl. J. Hyg. 2014;3(3):38-44.

Kumar P, Rao J, Haribabu Y, Manjunath. Microbiological Quality of Meat Collected from Municipal Slaughter Houses and Retail Meat Shops from Hyderabad Karnataka Region, India. APCBEE Procedia [Internet]. Elsevier B.V.; 2014. p. 364-9. Available from:

http://linkinghub.elsevier.com/retrieve/pii/S221267081400150X. Accessed 10 March 2019

Lawan et al. Evaluation of physical facilities and processing operations of major abattoirs in North-western states of Nigeria. Sokoto J. Vet. Sci. 2013;11(1):56-61.

Maharjan S, Rayamajhee B, Chhetri VS, Sherchan SP, Panta OP. Microbial quality of poultry meat in an ISO 22000: 2005 certified poultry processing plant of Kathmandu valley. Int. J. food c. International Joumal of Food Contamination; 2019;6(8).

Microgen. A Guide to Environmental Microbiological Testing for the Food Industry [Internet]. Camberley, Surrey England; 2016. Available from: http://microgenbioproducts.com/wp-content/uploads/sites/8/2016/02/Path-Chek-Guide-to-Environmental-Monitoring_09.05.08-_9_.pdf

Page $8 / 13$ 
Mirembe B, Ndejjo R, Musoke D. Sanitation and Hygiene status of butcheries in Kampala, Uganda. African J. food, Agric. Nutr. Dev. 2015;15(3):1-8.

Muinde O, Kuria E. Hygienic and sanitary practices of vendors of street foods. African J. food Agric. Nutr. Dev. 2005;5(1).

Mwangi LW, Matofari JW, Muliro PS, Bebe BO. Hygienic assessment of spontaneously fermented raw camel milk ( suusa ) along the informal value chain in Kenya. Int. J. Food Contam. [Internet]. Intemational Journal of Food Contamination; 2016;3(18). Available from: http://dx.doi.org/10.1186/s40550-016-0040-8

Nouichi S, Mossadak HT. Superficial Bacterial Contamination of Ovine and Bovine Carcasses at El-Harrach Slaughterhouse (Algeria ). Eur. J. Sci. Res. 2009;38(3):pp.474-485.

Obeng AK, Johnson FS, Appenteng SO. Microbial Quality of Fresh Meat from Retail Outlets in Tolon and Kumbungu Districts of the Northern Region of Ghana. Int. J. Sci. Technol. 2013;2(6):423-8.

PEH. Annual Summary of Outbreaks in New Zealand, 2007 [Internet]. 2008. Available from: https://surv.esr.cri.nz/surveillance/annual_outbreak.php? we_objectID=4167. Accessed 21 April 2019

Rani Z, Hugo A, Hugo C, Vimiso P, Muchenje V. Effect of post-slaughter handling during distribution on microbiological quality and safety of meat in the formal and informal sectors of South Africa: A review. S. Afr. J. Anim. Sci. 2017;47(3).

Ray B. Fundamental food Microbiology. 3rd Ed. Boca Raton: CRC Press Taylor \& Francis Group; 2005.

Shojaei H, Shooshtaripoor J, Amiri M. Efficacy of simple hand-washing in reduction of microbial hand contamination of Iranian food handlers. Food Res. Int. 2006;39(5):525-9.

Da Silva N, Hiromitaniwaki M, Junqueira V, Silveira N, Nascimento M, Gomes R. Microbiological Examination Methods of Food and Water. A laboratory manual. 6000 Broken Sound Parkway NW, Suite 300 Boca: CRC Press Taylor \& Francis Group; 2013.

Al Suwaidi, A .H.E., Hussein H, Al Faisal W, El Sawaf E, Wasfy A. Hygienic Practices Among Food Handlers in Dubai. Int. J. Prev. Med. Reserach. 2015;1(3):101-8.

Wambui J, Karuri E, Lamuka P, Matofari J. Good Hygiene Practices among Meat Handlers in Small and Medium Enterprise Slaughterhouses in Kenya. Food Control. Elsevier B.V.; 2017;5(36).

Birhanu W, Weldegebriel S, Bassazin G, Mitku F, Birku L, Tadesse M. Assesment of Microbiological Quality and Meat Handling Practices in Butcher Shops and Abattoir Found in Gondar Town, Ethiopia. Int. J. Microbiol. Res. 2017;8(2):59-68.

\section{Tables}

Table 2: Overall microbial quality (Mean \pm SEM) of beef (Carcass) in Uganda

\begin{tabular}{|c|c|c|c|c|c|}
\hline \multirow[t]{3}{*}{$\begin{array}{l}\text { Microbial } \\
\text { Parameter }\end{array}$} & \multicolumn{2}{|c|}{$\begin{array}{l}\text { Overall microbial load } \\
\left(\log \left(\mathrm{cfu} / \mathrm{cm}^{2}\right)\right.\end{array}$} & \multicolumn{3}{|c|}{ Microbial limits } \\
\hline & $\begin{array}{c}\text { Slaughter House } \\
(\mathrm{n}=34)\end{array}$ & $\begin{array}{c}\text { Butchery } \\
(n=30)\end{array}$ & $\begin{array}{c}\text { Satisfactory (safe level) } \\
\left(\log \left(\mathrm{cfu} / \mathrm{cm}^{2}\right)\right.\end{array}$ & $\begin{array}{c}\text { Acceptable } \\
\left(\log \left(\mathrm{cfu} / \mathrm{cm}^{2}\right)\right.\end{array}$ & $\begin{array}{l}\text { Unsatisfactory level } \\
\left(\log \left(\mathrm{cfu} / \mathrm{cm}^{2}\right)\right.\end{array}$ \\
\hline & Mean \pm SEM & Mean \pm SEM & & & \\
\hline TVC & $5.32 \pm 0.30^{*}$ & $6.05 \pm 0.34^{*}$ & $<3.5$ & $3.5-5$ & $>5.0$ \\
\hline TCC & $1.60 \pm 0.26$ & $2.40 \pm 0.23^{*}$ & $<1.5$ & $1.5-2.5$ & $>2.5$ \\
\hline E. coli & $0.58 \pm 0.18^{*}$ & $0.86 \pm 0.22^{*}$ & 0 & 0 & $>0$ \\
\hline S. aureus & $3.21 \pm 0.30^{*}$ & $4.02 \pm 0.17 *$ & $<2.0$ & $2-3$ & $>3$ \\
\hline
\end{tabular}

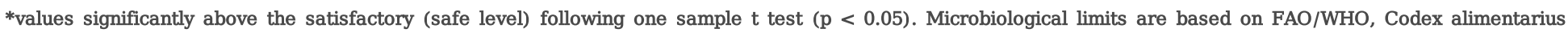

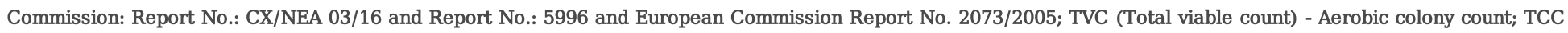
(Total Coliform Count)- Enterobacteriaceae 
Table 1: Mean \pm SEM for Microbial counts $\left(\log _{10} \mathrm{cfu} / \mathrm{cm}^{2}\right)$ from tools, surfaces, personnel hands and clothes at slaughter and butchery in Study Districts

\begin{tabular}{|c|c|c|c|c|c|c|c|c|c|}
\hline & & \multicolumn{2}{|c|}{ TVC } & \multicolumn{2}{|c|}{ TCC } & \multicolumn{2}{|c|}{ E. coli } & \multicolumn{2}{|c|}{ S. aureus } \\
\hline & & SL & BT & SL & BT & SL & BT & SL & BT \\
\hline \multirow{7}{*}{$\begin{array}{l}\text { Mbale } \\
(\mathrm{nS}=45, \\
\mathrm{nB}=48)\end{array}$} & $\begin{array}{l}\text { Hands (nS=10, } \\
\mathrm{nB}=5)\end{array}$ & $3.99 \pm 0.33^{\mathrm{i}, \mathrm{a}}$ & $5.38 \pm 0.45^{\mathrm{i}, \mathrm{b}}$ & $0^{i}$ & $2.19 \pm 0.95^{i}$ & 0 & $0.40 \pm 0.40^{i}$ & $2.65 \pm 0.14^{\mathrm{i}, \mathrm{c}}$ & $3.41 \pm 0.48^{i, c}$ \\
\hline & Clothes (nS=15) & $3.30 \pm 0.17^{\mathrm{ii}}$ & - & $2.97 \pm 0.18^{\mathrm{iii}}$ & - & - & - & $3.05 \pm 0.11^{\mathrm{i}}$ & - \\
\hline & $\begin{array}{l}\text { Machete }(\mathrm{nS}=5 \\
\mathrm{nB}=5)\end{array}$ & $4.71 \pm 0.20^{i, d}$ & $5.66 \pm 0.42^{i, d}$ & $2.98 \pm 0.22^{\mathrm{iii}, \mathrm{e}}$ & $3.82 \pm 0.60^{\mathrm{i}, \mathrm{ii}, \mathrm{e}}$ & 0 & $0.66 \pm 0.66^{i}$ & $3.60 \pm 0.35^{i, f}$ & $4.57 \pm 0.64^{i, f}$ \\
\hline & $\begin{array}{l}\text { Knives ( } \mathrm{nS}=12 \text {, } \\
\mathrm{nB}=10)\end{array}$ & $4.18 \pm 0.11^{i, g}$ & $4.16 \pm 0.11^{\mathrm{ii}, \mathrm{g}}$ & $1.52 \pm 0.54^{\mathrm{ii}, \mathrm{h}}$ & $1.34 \pm 0.55^{\mathrm{i}, \mathrm{h}}$ & 0 & $0^{\mathrm{i}}$ & $2.50 \pm 0.70^{i, j}$ & $2.29 \pm 0.65^{i, i i, j}$ \\
\hline & CB $(n B=10$ & - & $4.16 \pm 0.17^{\mathrm{ii}}$ & - & $3.13 \pm 0.27^{\mathrm{i}, \mathrm{ii}}$ & - & $0.68 \pm 0.35^{i}$ & - & $2.57 \pm 0.44^{\mathrm{i}, \mathrm{ii}}$ \\
\hline & WT $(n B=18)$ & - & $4.55 \pm 0.28^{\mathrm{i}, \mathrm{ii}}$ & - & $2.55 \pm 0.26^{\mathrm{i}, \mathrm{ii}}$ & - & $0.22 \pm 0.15^{i}$ & - & $3.58 \pm 0.19^{i}$ \\
\hline & Floor (nS=3) & $4.59 \pm 0.13^{i}$ & - & $2.68 \pm 0.21^{\mathrm{ii}, \mathrm{iii}}$ & - & $2.10 \pm 0.10$ & - & $2.69 \pm 0.35^{i}$ & - \\
\hline \multirow{7}{*}{$\begin{array}{l}\text { Mbarara } \\
(\mathrm{nS}=31 \\
\mathrm{nB}=56)\end{array}$} & $\begin{array}{l}\text { Hands ( } \mathrm{nS}=8 \text {, } \\
\mathrm{nB}=10 \text { ) }\end{array}$ & $5.74 \pm 0.58^{i, k}$ & $6.28 \pm 0.69^{\mathrm{i}, \mathrm{k}}$ & $0.69 \pm 0.45^{\mathrm{i}, 1}$ & $1.15 \pm 0.51^{\mathrm{i}, \mathrm{iii}, 1}$ & $0.54 \pm 0.35^{i, m}$ & $0.48 \pm 0.32^{\mathrm{i}, \mathrm{ii}, \mathrm{m}}$ & $4.37 \pm 0.33^{i, n}$ & $4.45 \pm 0.43^{i, n}$ \\
\hline & $\begin{array}{l}\text { Clothes ( } \mathrm{nS}=8 \text {, } \\
\mathrm{nB}=8 \text { ) }\end{array}$ & $8.33 \pm 0.27^{\mathrm{ii}, \mathrm{o}}$ & $8.38 \pm 0.28^{\mathrm{ii}, o}$ & $0^{i}$ & $0^{i}$ & $0^{\mathrm{i}, \mathrm{ii}}$ & $0^{i}$ & $4.96 \pm 0.73^{i, p}$ & $5.05 \pm 0.71^{i, p}$ \\
\hline & $\begin{array}{l}\text { Machete }(\mathrm{nS}=7 \text {, } \\
\mathrm{nB}=10)\end{array}$ & $5.68 \pm 0.78^{i, q}$ & $6.33 \pm 0.64^{i, q}$ & $1.86 \pm 0.66^{\mathrm{ii}, \mathrm{r}}$ & $1.98 \pm 0.58^{\mathrm{i}, \mathrm{ii}, \mathrm{iii}, \mathrm{r}}$ & $1.25 \pm 0.45^{\mathrm{i}, \mathrm{s}}$ & $0.78 \pm 0.40^{\mathrm{i}, \mathrm{ii}, \mathrm{s}}$ & $3.71 \pm 0.42^{i, t}$ & $4.18 \pm 0.33^{\mathrm{i}, \mathrm{ii}, \mathrm{t}}$ \\
\hline & $\begin{array}{l}\text { Knives ( } \mathrm{nS}=4 \text {, } \\
\mathrm{nB}=10 \text { ) }\end{array}$ & $6.99 \pm 0.67^{\mathrm{i}, \mathrm{ii}, \mathrm{u}}$ & $5.79 \pm 0.60^{i, u}$ & $0^{i}$ & $2.03 \pm 0.58^{\mathrm{i}, \mathrm{ii}, \mathrm{iii}}$ & $0^{\mathrm{i}, \mathrm{ii}}$ & $0.83 \pm 0.34^{\mathrm{i}, \mathrm{ii}}$ & $3.45 \pm 1.26^{i, v}$ & $3.04 \pm 0.41^{i i, v}$ \\
\hline & $\mathrm{CB}(\mathrm{nB}=8)$ & - & $7.02 \pm 0.62^{\mathrm{i}, \mathrm{ii}}$ & - & $2.52 \pm 0.57^{\mathrm{i}, \mathrm{ii}}$ & - & $1.15 \pm 0.44^{\mathrm{i}, \mathrm{ii}}$ & - & $4.77 \pm 0.18^{i}$ \\
\hline & $\mathrm{WT}(\mathrm{nB}=10)$ & - & $6.50 \pm 0.55^{i}$ & - & $1.03 \pm 0.43^{\mathrm{i}, \mathrm{iii}}$ & - & $0.43 \pm 0.29^{\mathrm{i}, \mathrm{ii}}$ & - & $3.61 \pm 0.67^{\mathrm{i}, \mathrm{ii}}$ \\
\hline & Floor $(\mathrm{nS}=4)$ & $6.77 \pm 0.53^{\mathrm{i}, \mathrm{ii}}$ & - & $2.35 \pm 0.13^{\mathrm{ii}}$ & - & $0^{\mathrm{i}, \mathrm{ii}}$ & - & $4.15 \pm 0.03^{i}$ & - \\
\hline \multirow[t]{6}{*}{$\begin{array}{l}\text { Kampala } \\
\quad(n S=23, \\
\mathrm{nB}=50)\end{array}$} & $\begin{array}{l}\text { Hands } \\
\mathrm{nB}=10) \\
\text { Clothes } \\
\mathrm{nB}=4)\end{array} \quad(\mathrm{nS}=6$, & $\begin{array}{l}4.42 \pm 0.49^{i, i i i, w} \\
4.84 \pm 0.61^{i, i i i, y}\end{array}$ & $\begin{array}{l}4.70 \pm 0.28^{\mathrm{i}, \mathrm{w}} \\
4.93 \pm 0.58^{\mathrm{i}, \mathrm{ii}, \mathrm{y}}\end{array}$ & $2.02 \pm 0.69^{i i, z}$ & $\begin{array}{l}0.77 \pm 0.40^{i} \\
2.08 \pm 0.70^{i, z}\end{array}$ & $1.79 \pm 0.62^{\mathrm{ii}, \mathrm{A}}$ & $\begin{array}{c}0^{\mathrm{i}} \\
1.91 \pm 0.65^{\mathrm{ii}, \mathrm{A}}\end{array}$ & $\begin{array}{l}2.40 \pm 1.08^{\mathrm{i}, \mathrm{x}} \\
3.41 \pm 0.62^{\mathrm{i}, \mathrm{B}}\end{array}$ & $\begin{array}{l}3.35 \pm 0.28^{\mathrm{i}, \mathrm{x}} \\
3.60 \pm 0.56^{\mathrm{i}, \mathrm{ii}, \mathrm{B}}\end{array}$ \\
\hline & $\begin{array}{l}\text { Machete } \quad(\mathrm{nS}=6, \\
\mathrm{nB}=10)\end{array}$ & $3.36 \pm 0.12^{\mathrm{i}, \mathrm{iii}, \mathrm{C}}$ & $6.19 \pm 0.38^{\mathrm{ii}, \mathrm{D}}$ & $2.65 \pm 0.10^{\mathrm{ii}, \mathrm{E}}$ & $1.80 \pm 0.40^{\mathrm{i}, \mathrm{E}}$ & $0.72 \pm 0.46^{\mathrm{i}, \mathrm{ii}}$ & $0^{i}$ & $0^{i i}$ & $3.34 \pm 0.62^{i}$ \\
\hline & $\begin{array}{l}\text { Knives } \quad(\mathrm{nS}=3, \\
\mathrm{nB}=6)\end{array}$ & $4.52 \pm 0.52^{\mathrm{i}, \mathrm{iii}, \mathrm{F}}$ & $4.29 \pm 0.32^{\mathrm{i}, \mathrm{F}}$ & $1.93 \pm 0.99^{\mathrm{ii}, \mathrm{G}}$ & $1.44 \pm 0.65^{\mathrm{i}, \mathrm{G}}$ & $1.49 \pm 0.76^{\mathrm{ii}, \mathrm{H}}$ & $1.18 \pm 0.53^{\mathrm{iii}, \mathrm{H}}$ & $1.17 \pm 1.17^{\mathrm{i}, \mathrm{ii}, \mathrm{I}}$ & $1.69 \pm 0.75^{\mathrm{ii}, \mathrm{I}}$ \\
\hline & $C B(n B=10)$ & - & $5.30 \pm 0.40^{\mathrm{i}, \mathrm{ii}}$ & - & $1.37 \pm 0.38^{i}$ & - & $0^{\mathrm{i}}$ & - & $3.62 \pm 0.36^{i}$ \\
\hline & WT (nB=10) & - & $3.77 \pm 0.42^{\mathrm{i}}$ & - & $1.05 \pm 0.44^{\mathrm{i}}$ & - & $0^{\mathrm{i}}$ & - & $1.83 \pm 0.51^{\mathrm{ii}}$ \\
\hline & Floor $(\mathrm{nS}=4)$ & $6.35 \pm 0.56^{\mathrm{ii}}$ & - & $2.80 \pm 0.04^{\mathrm{ii}}$ & - & $1.58 \pm 0.53^{i \mathrm{i}}$ & - & $3.67 \pm 0.88^{i}$ & - \\
\hline \multirow[t]{3}{*}{ All swabs } & $\begin{array}{l}\text { Mbale } \quad(\mathrm{nS}=45, \\
\mathrm{nB}=48)\end{array}$ & $3.93 \pm 0.12^{\mathrm{i}, \mathrm{J}}$ & $4.59 \pm 0.15^{\mathrm{i}, \mathrm{K}}$ & $1.90 \pm 0.24^{\mathrm{i}, \mathrm{L}}$ & $2.51 \pm 0.22^{\mathrm{i}, \mathrm{L}}$ & $0.14 \pm 0.08^{i, M}$ & $0.34 \pm 0.12^{i, M}$ & $2.85 \pm 0.20^{\mathrm{i}, \mathrm{N}}$ & $3.18 \pm 0.21^{i, N}$ \\
\hline & $\begin{array}{l}\text { Mbarara(nS=31, } \\
\mathrm{nB}=56)\end{array}$ & $6.69 \pm 0.32^{\mathrm{ii}, \mathrm{O}}$ & $6.65 \pm 0.26^{\mathrm{i}, \mathrm{O}}$ & $0.90 \pm 0.24^{\mathrm{ii}, \mathrm{P}}$ & $1.47 \pm 0.22^{\mathrm{ii}, \mathrm{P}}$ & $0.42 \pm 0.16^{\mathrm{i}, \mathrm{Q}}$ & $0.61 \pm 0.14^{\mathrm{i}, Q}$ & $4.23 \pm 0.28^{\mathrm{ii}, \mathrm{R}}$ & $4.13 \pm 0.21^{\mathrm{ii}, \mathrm{R}}$ \\
\hline & $\begin{array}{l}\text { Kampala }(\mathrm{nS}=23 \text {, } \\
\mathrm{nB}=50)\end{array}$ & $4.57 \pm 0.28^{\mathrm{i}, \mathrm{S}}$ & $4.90 \pm 0.19^{\mathrm{i}, \mathrm{S}}$ & $1.78 \pm 0.28^{\mathrm{i}, \mathrm{T}}$ & $1.34 \pm 0.19^{\mathrm{ii}, \mathrm{T}}$ & $0.97 \pm 0.24^{\mathrm{ii}, \mathrm{U}}$ & $0.29 \pm 0.11^{\mathrm{i}, \mathrm{V}}$ & $2.01 \pm 0.45^{\mathrm{iii}, \mathrm{W}}$ & $2.92 \pm 0.23^{\mathrm{i}, \mathrm{X}}$ \\
\hline \multirow[t]{6}{*}{ All districts } & $\begin{array}{l}\text { Hands ( } \mathrm{nS}=24, \\
\mathrm{nB}=25) \\
\text { Clothes }(\mathrm{nS}=27, \\
\mathrm{nB}=12)\end{array}$ & $\begin{array}{l}4.68 \pm 0.30^{\mathrm{i}, \mathrm{Y}} \\
5.02 \pm 0.46^{\mathrm{i}, \mathrm{ii}, \mathrm{D}}\end{array}$ & $\begin{array}{l}5.46 \pm 0.33^{\mathrm{i}, \mathrm{Y}} \\
7.23 \pm 0.55^{\mathrm{ii}, \mathrm{E}}\end{array}$ & $\begin{array}{l}0.23 \pm 0.16^{\mathrm{i}, \mathrm{Z}} \\
1.95 \pm 0.29^{\mathrm{ii}, \mathrm{iii}, \mathrm{F}}\end{array}$ & $\begin{array}{l}1.21 \pm 0.32^{\mathrm{i}, \mathrm{A}} \\
0.69 \pm 0.36^{\mathrm{i}, \mathrm{ii}, \mathrm{G}}\end{array}$ & $\begin{array}{l}0.18 \pm 0.12^{\mathrm{i}, \mathrm{B}} \\
0.26 \pm 0.15^{\mathrm{i}, \mathrm{ii}, \mathrm{H}}\end{array}$ & $\begin{array}{l}0.27 \pm 0.15^{\mathrm{i}, \mathrm{B}} \\
0.64 \pm 0.33^{\mathrm{i}, \mathrm{H}}\end{array}$ & $\begin{array}{l}3.16 \pm 0.33^{\mathrm{i}, \mathrm{ii}, \mathrm{C}} \\
3.67 \pm 0.28^{\mathrm{i}, \mathrm{I}}\end{array}$ & $\begin{array}{l}3.80 \pm 0.24^{\mathrm{i}, \mathrm{C}} \\
4.56 \pm 0.54^{\mathrm{i}, \mathrm{I}}\end{array}$ \\
\hline & $\begin{array}{l}\text { Machete }(\mathrm{nS}=18 \text {, } \\
\mathrm{nB}=25)\end{array}$ & $4.64 \pm 0.38^{i, J}$ & $6.14 \pm 0.30^{\mathrm{i}, \mathrm{ii}, \mathrm{K}}$ & $2.43 \pm 0.28^{\mathrm{ii}, \mathrm{L}}$ & $2.28 \pm 0.34^{\mathrm{ii}, \mathrm{L}}$ & $0.73 \pm 0.25^{\mathrm{ii}, \mathrm{iii}, \mathrm{M}}$ & $0.44 \pm 0.21^{\mathrm{i}, \mathrm{M}}$ & $2.44 \pm 0.46^{\mathrm{i}, \mathrm{ii}, \mathrm{N}}$ & $3.92 \pm 0.31^{\mathrm{i}, \mathrm{O}}$ \\
\hline & $\begin{array}{l}\text { Knives ( } \mathrm{nS}=19 \text {, } \\
\mathrm{nB}=26 \text { ) }\end{array}$ & $4.82 \pm 0.31^{\mathrm{i}, \mathrm{ii}, \mathrm{P}}$ & $4.82 \pm 0.28^{i, P}$ & $1.26 \pm 0.39^{\mathrm{iii}, \mathrm{Q}}$ & $1.63 \pm 0.33^{\mathrm{i}, \mathrm{ii}, \mathrm{Q}}$ & $0.24 \pm 0.16^{\mathrm{i}, \mathrm{ii}, \mathrm{R}}$ & $0.59 \pm 0.20^{\mathrm{i}, \mathrm{R}}$ & $2.49 \pm 0.54^{\mathrm{i}, \mathrm{ii}, \mathrm{S}}$ & $2.44 \pm 0.35^{\mathrm{ii}, \mathrm{S}}$ \\
\hline & $\mathrm{CB}(\mathrm{nS}=0, \mathrm{nB}=28)$ & - & $5.39 \pm 0.32^{i}$ & - & $2.33 \pm 0.27^{i i}$ & - & $0.57 \pm 0.19^{i}$ & - & $3.57 \pm 0.26^{i}$ \\
\hline & $\mathrm{WT}((\mathrm{nS}=0, \mathrm{nB}=38)$ & - & $4.86 \pm 0.28^{\mathrm{i}}$ & - & $1.76 \pm 0.23^{\mathrm{i}, \mathrm{ii}}$ & - & $0.22 \pm 0.10^{\mathrm{i}}$ & - & $3.13 \pm 0.26^{\mathrm{i}, \mathrm{ii}}$ \\
\hline & $\begin{array}{l}\text { Floor }(\mathrm{nS}=11 \text {, } \\
\mathrm{nB}=0)\end{array}$ & $6.02 \pm 0.38^{i i}$ & - & $2.60 \pm 0.09^{\mathrm{ii}}$ & - & $1.15 \pm 0.33^{\mathrm{iii}}$ & - & $3.58 \pm 0.35^{\mathrm{i}, \mathrm{ii}}$ & - \\
\hline
\end{tabular}

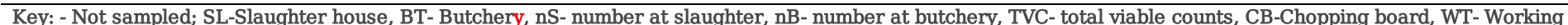

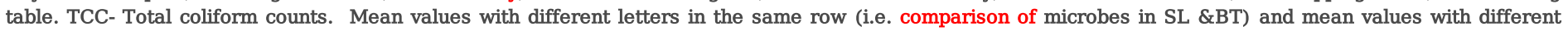

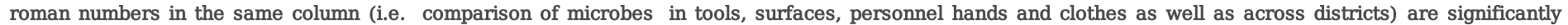
different $(p<0.05)$. 
Table 3: Compliance requirements for slaughter houses and butchery establishments Slaughter house establishments

\begin{tabular}{|c|c|c|c|}
\hline Good practices & Kampala $(n=5)$ & Mbarara $(n=4)$ & Mbale $(n=4)$ \\
\hline Lairage & $5(100 \%)$ & $1(25 \%)$ & $1(25 \%)$ \\
\hline Slaughter hall & $5(100 \%)$ & $4(100 \%)$ & $4(100 \%)$ \\
\hline Rail system & $5(100 \%)$ & $1(25 \%)$ & $1(25 \%)$ \\
\hline Gut \& tripe room & $5(100 \%)$ & 0 & 0 \\
\hline Cold room/Carcass chilling area & $5(100 \%)$ & 0 & 0 \\
\hline Easy to clean surface floor & $5(100 \%)$ & $4(100 \%)$ & $4(100 \%)$ \\
\hline Detained meat room & $2(40 \%)$ & 0 & 0 \\
\hline Incinerator for condemned meat & $1(20 \%)$ & $1(25 \%)$ & $1(25 \%)$ \\
\hline Cutting room & $5(100 \%)$ & $4(100 \%)$ & $4(100 \%)$ \\
\hline Drainage system & $3(60 \%)$ & $1(25 \%)$ & $1(25 \%)$ \\
\hline Adequate ventilation & $5(100 \%)$ & $4(100 \%)$ & $4(100 \%)$ \\
\hline Portable Water supply & $5(100 \%)$ & $1(25 \%)$ & $1(25 \%)$ \\
\hline Electricity supply & $5(100 \%)$ & $1(25 \%)$ & $1(25 \%)$ \\
\hline Toilet facilities & $5(100 \%)$ & $1(25 \%)$ & $1(25 \%)$ \\
\hline Changing room & $5(100 \%)$ & $1(25 \%)$ & $1(25 \%)$ \\
\hline$\%$ compliance of slaughter houses & 88 & 40 & 40 \\
\hline \multicolumn{4}{|l|}{ Butchery establishments } \\
\hline \multicolumn{4}{|c|}{ Number of butcheries abiding with requirements } \\
\hline Good practices & Kampala $(\mathrm{n}=18)$ & Mbarara $(n=18)$ & Mbale (n=15) \\
\hline Availability of water & $2(11 \%)$ & 0 & 0 \\
\hline Ambient meat storage & $3(17 \%)$ & 0 & 0 \\
\hline Insect proof window \& doors & $3(17 \%)$ & 0 & 0 \\
\hline Stainless steel tools & $18(100 \%)$ & $18(100 \%)$ & $15(100 \%)$ \\
\hline Availability of preparation room & $3(17 \%)$ & 0 & 0 \\
\hline Easy to clean sales counter & $8(44 \%)$ & 0 & $5(33 \%)$ \\
\hline Waste disposal point & $8(44 \%)$ & 2 & $4(27 \%)$ \\
\hline Standard butchery structure & $3(17 \%)$ & 0 & 0 \\
\hline$\%$ compliance at the butchery & 33 & 14 & 20 \\
\hline
\end{tabular}

Key: (0) indicates no compliance and (n) indicates the number of butcheries/slaughter houses visited

\section{Figures}




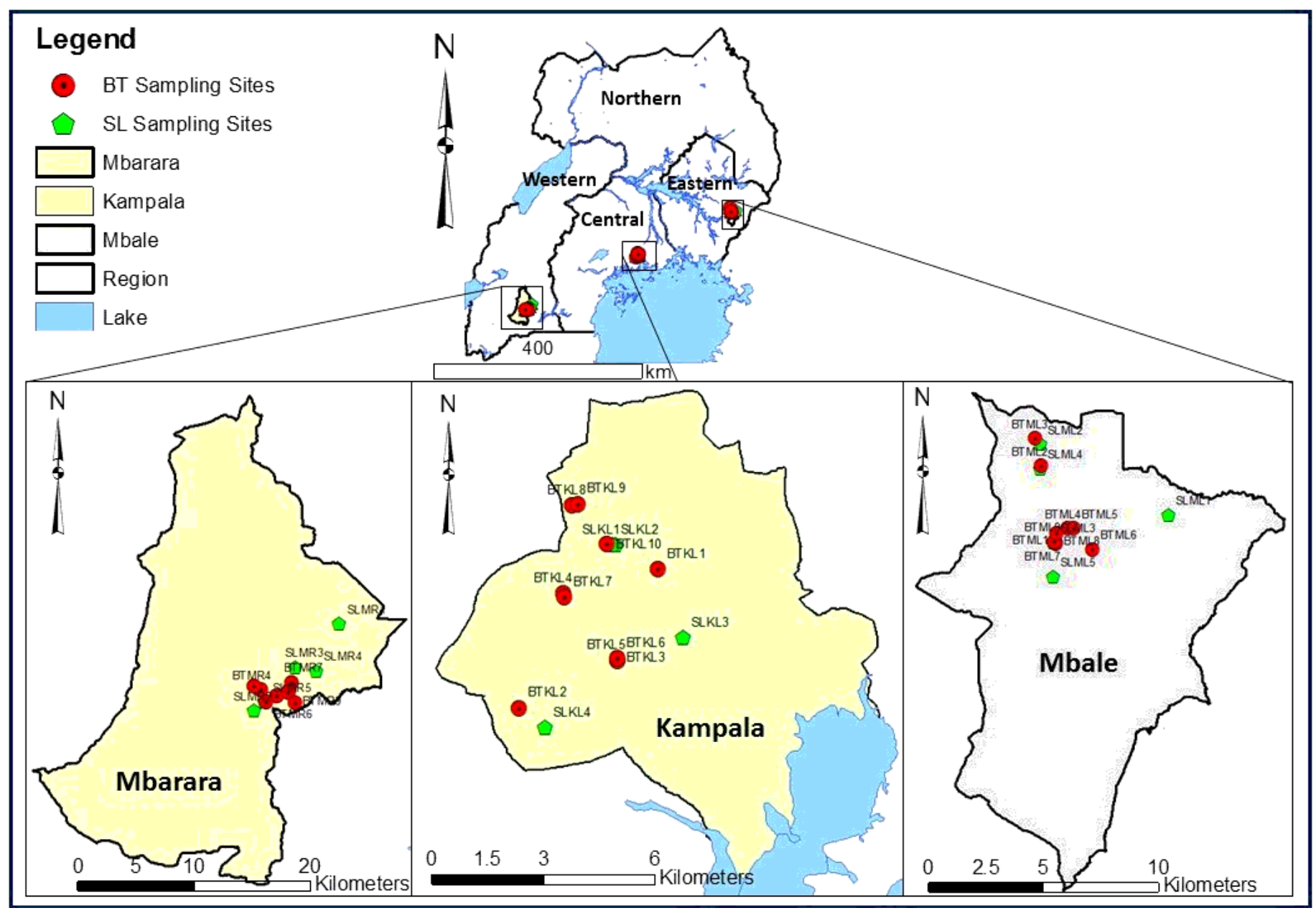

Figure 1

Map of Uganda showing the study Districts (BT=Butchery, SL=Slaughter house).

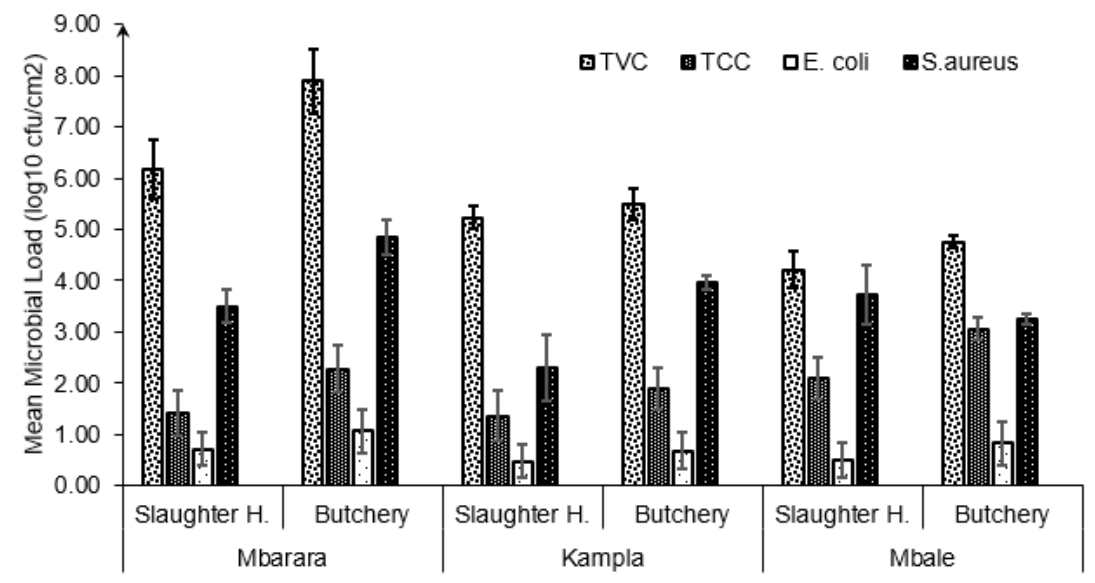

Figure 2

Mean \pm SEM Microbial load in carcass at slaughter house $(H$.) and butchery 


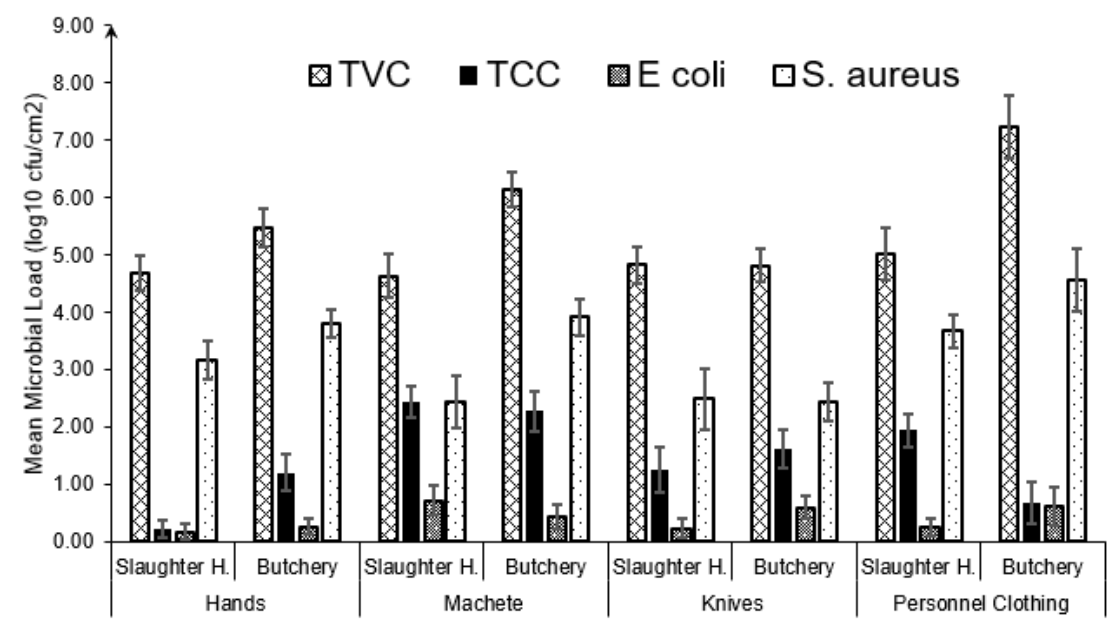

Figure 3

Comparison of overall microbial load on hands, tools and personnel protective clothing at slaughter house $(\mathrm{H}$.) and butchery. All data are presented as mean $\pm S E M$

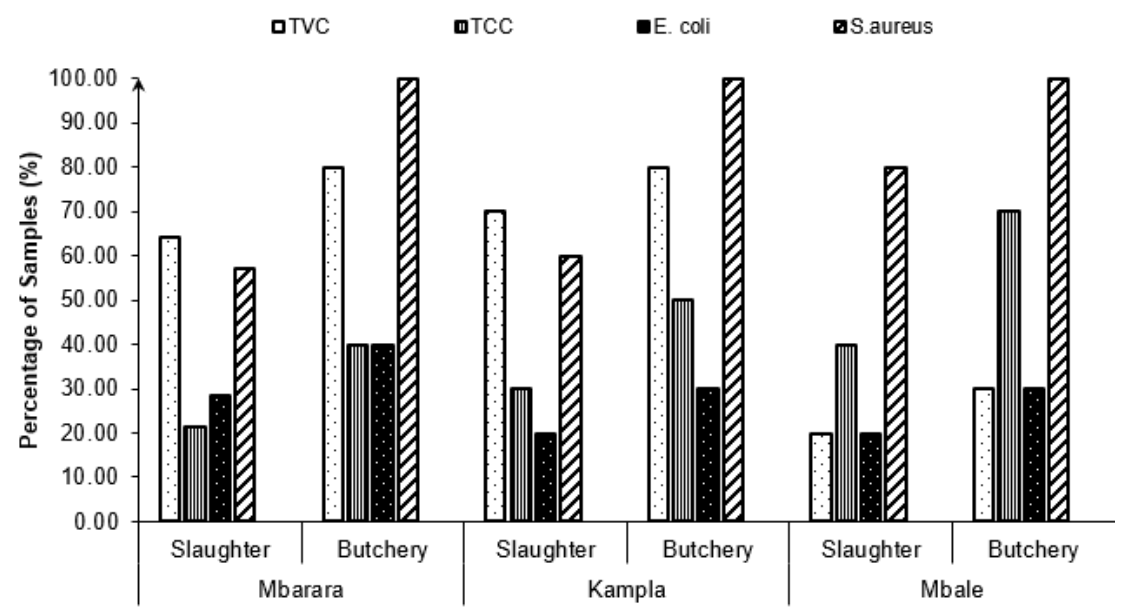

Figure 4

Percentage of carcass samples above the expected microbial safe levels 